\title{
Biomarker model for cancer: \\ Development of fast LC-MS/MS method for reduced and oxidized glutathione
}

\author{
Ray F. Nassar, Praneeth Chitralia, Roger Rushworth ${ }^{1}$, Charles O'Donnell ${ }^{\mathbf{1}}$, Iswarya \\ Gagrin'2. ${ }^{1}$ Engineering and Science University Magnet School, 500 Boston Post Road, West \\ Haven, CT, USA, ${ }^{2}$ Chemistry \& Chemical Engineering Department University of New Haven, \\ 300 Boston Post Rd, West Haven, CT, USA
}

\begin{abstract}
In recent years, there have been significant efforts devoted to countering the challenge of detecting cancer in early stages. Reduced glutathione (GSH) plays an important role in the antioxidant system and is required for the maintenance of the redox status of the cell, defense against free radicals and detoxification of toxic compounds. GSH may be converted to oxidized glutathione (GSSG) during the oxidative stress that it regularly undergoes when combating cancer cells. Therefore, the ratio of GSH to the total amount of glutathione can be an extremely useful biomarker for detecting cancer. However, there has yet to be an effective method of detecting and quantifying glutathione in cells, making it extremely difficult to use as a biomarker. In this study, we have created an effective method of detecting both forms of glutathione, utilizing highperformance liquid chromatography-tandem mass spectrometry (HPLC-MS/MS). The analysis time took less than 1 minute, and we were able to quantify both GSH and GSSG in one method. The limit of quantitation is $1 \mathrm{ng} / \mathrm{mL}$, and we ran three trials, each examining a range of concentrations, from 1 to $500 \mathrm{ng} / \mathrm{ml}$ of GSH and GSSG. Results were calculated using peak area ratios, using HPLC-MS/MS technology, we were able to determine both the amounts of GSH and GSSG in a single method, creating a fast, reliable, non-invasive, and cost-effective method of testing early stages of cancer.
\end{abstract}

\section{Introduction}

In normal conditions, cells will have glutathione, an antioxidant, which engages in a variety of functions, most involved in maintaining cellular redox homeostasis. Glutathione is the prevalent antioxidant in mammals, normally having a concentration of 1-10 mM. Reduced glutathione (GSH) also has an inactive, oxidized version (GSSG) (Figure 1). The chemical structures formula of both types of glutathione (GSH, GSSG).

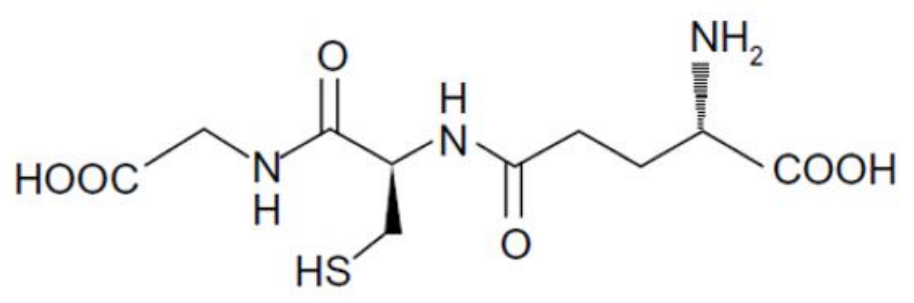

GSH: $\mathrm{C}_{10} \mathrm{H}_{17} \mathrm{~N}_{3} \mathrm{O}_{6} \mathrm{~S}=307.33$

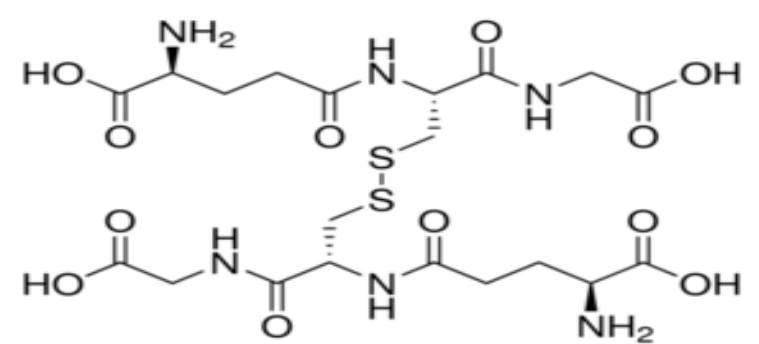

GSSG: $\mathrm{C}_{20} \mathrm{H}_{32} \mathrm{~N}_{6} \mathrm{O}_{12} \mathrm{~S}_{2}=612.66$ 


\section{Figure 1. The skeletal formulae and structures of both types of glutathione (GSH, GSSG)}

In cancer cells, there is a higher amount of antioxidants in cells than standard. Cells maintain a balance of antioxidants (GSH) against Reactive oxygen species generated by the different physiological processes. (Ankita Bansal and M. Celeste Simon, J. Cell Biol. 2018 Vol. 217 No. 7). During the oxidative stress that cells endure while countering cancer, reduced glutathione (GSH) may be converted to its oxidized version (GSSG) (Figure 2).

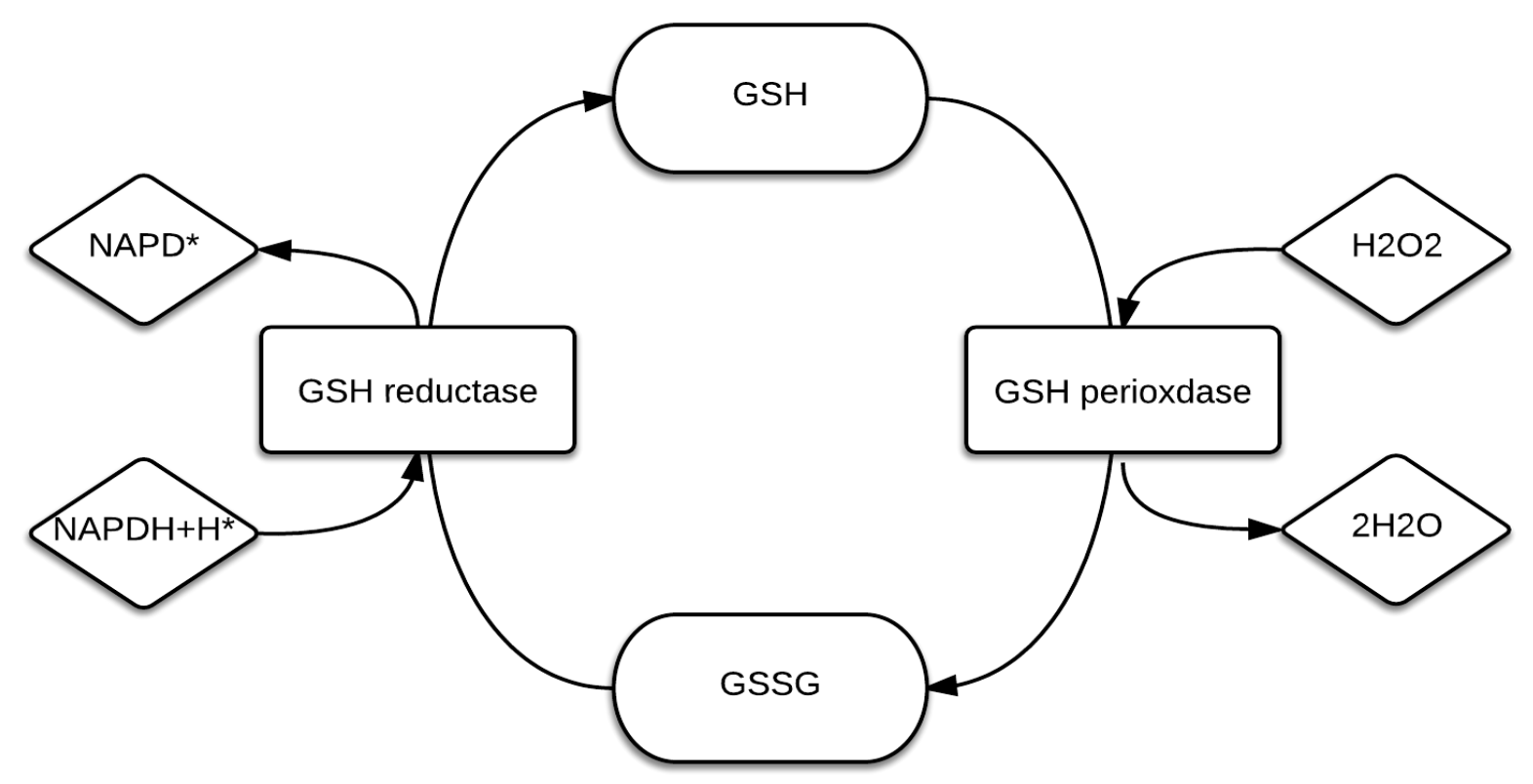

Figure 2. The cycle that GSH and GSSG go through to be converted to one another

GSH and GSSG have been measured by a number of methods. Although several methods are available for measuring GSH and GSSG, all have disadvantages including the need to generate derivatives, the inability to conveniently measure both GSH and GSSG, and lack of enough sensitivity to allow detection in small samples. We have developed a simple and sensitive liquid chromatography-tandem mass spectrometry (LC-MS/MS) method for GSH and GSSG. The assay, a fast and reliable method to measure oxidized and reduced form of glutathione was developed. 
Principles of the method: This method was designed to detect GSH and GSSG using LC-MS/MS. The standard curve range was $5-1000 \mathrm{ng} / \mathrm{mL}$.

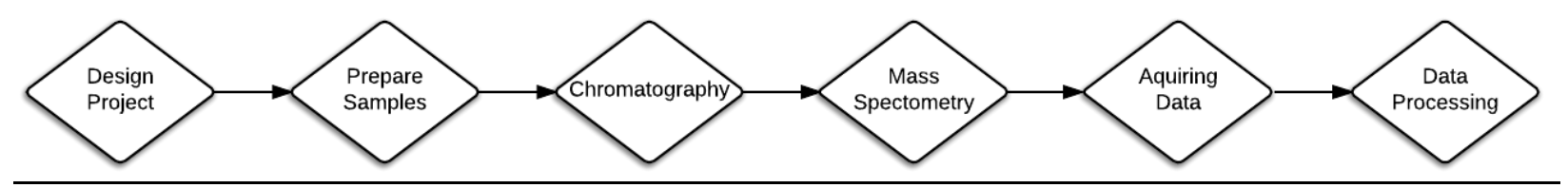

Figure 3. A flowchart depicting numerous steps in the method

Materials: Water, Ethanol, Formic Acid, GSH, GSSG (all bought by Sigma Aldrich)

Instrumentation: LCMS (Sciex API 3000 triplequad and LC-Agilent)

Preparation of Stock Standard Solutions. Stock standard solutions for glutathione reduced form and glutathione oxidized form are prepared in duplicate and compared using the appropriate weight for the lot purity, moisture, and salt correction.

As shown in table 1 , place $200 \mu \mathrm{L}$ of the standard stock solution into a polypropylene vial and add $800 \mu \mathrm{L}$ of the diluent to the removed standard stock solution amount. The glutathione (reduced and oxidized) concentration in this solution [Std5] will be $1000.00 \mathrm{ng} / \mathrm{mL}$. Place $200 \mu \mathrm{L}$ of Std5 into a separate vial and add $800 \mu \mathrm{L}$ of the diluent to Std5, making the concentration of the solution [Std4] $200.00 \mathrm{ng} / \mathrm{mL}$ of glutathione. Place $100 \mu \mathrm{L}$ of Std4 into another separate vial and add 300 $\mu \mathrm{L}$ of diluent to the removed Std4. The solution's [Std3] concentration should then be $50.00 \mathrm{ng} / \mathrm{mL}$ of glutathione. Place $100 \mu \mathrm{L}$ of Std3 into another separate vial and add $400 \mu \mathrm{L}$ of diluent to the removed Std3; the glutathione concentration of the solution [Std2] will be $10.00 \mathrm{ng} / \mathrm{mL}$. Place 100 $\mu \mathrm{L}$ of Std2 into another separate vial and add $100 \mu \mathrm{L}$ of diluent to the removed Std2. The glutathione concentration of the solution [Std1] will be $5.00 \mathrm{ng} / \mathrm{mL}$. Place $25 \mu \mathrm{L}$ of Std1 into another separate vial and add $100 \mu \mathrm{L}$ of the diluent to the removed Std1, making the final solution's concentration $1.00 \mathrm{ng} / \mathrm{mL}$ of glutathione. All solutions are stored in polypropylene vials in a refrigerator set to maintain $2^{\circ} \mathrm{C}$ to $8^{\circ} \mathrm{C}$.

\begin{tabular}{|c|c|c|c|c|c|c|}
\hline \multicolumn{7}{|c|}{ Table 1. Calibra } \\
\hline \multicolumn{2}{|c|}{ Compound } & \multicolumn{2}{|c|}{ Glutothione } & \multirow{2}{*}{\multicolumn{2}{|c|}{$\mathrm{ng} / \mathrm{mL}$}} & \\
\hline \multicolumn{2}{|c|}{ Concentration } & \multicolumn{2}{|c|}{5000.00} & & & \\
\hline & & & Diluent & \multicolumn{3}{|c|}{$50 \%$ Ethanol Water (0.1\% Formic) } \\
\hline \multicolumn{6}{|c|}{ Solutions dire ctly into a utosampler vials } & \\
\hline \multicolumn{2}{|c|}{ Designations } & \multicolumn{3}{|c|}{ Dilutions } & \multicolumn{2}{|c|}{ Final Conce ntration(s) } \\
\hline Level & \begin{tabular}{|l|} 
Target \\
Conc.
\end{tabular} & $\begin{array}{c}\text { Take } \\
\text { Amount }\end{array}$ & Source & $\begin{array}{c}\text { Add } \\
\text { Diluent }\end{array}$ & Glutothione & $\begin{array}{c}\text { Remaining } \\
\text { Vol. }\end{array}$ \\
\hline Name & $(\mathbf{n g} / \mathbf{m L})$ & (uL) & solution & (uL) & $(\mathbf{n g} / \mathbf{m L})$ & (uL) \\
\hline Std5 & 1000 & 200 & stock & 800 & 1000.00 & 800 \\
\hline Std4 & 200 & 200 & std5 & 800 & 200.00 & 900 \\
\hline Std3 & 50 & 100 & std4 & 300 & 50.00 & 300 \\
\hline Std2 & 10 & 100 & std3 & 400 & 10.00 & 400 \\
\hline Std1 & 5 & 100 & std2 & 100 & 5.00 & 0.00 \\
\hline blank & 1 & 25.000 & std 1 & 100 & 1.00 & 0.00 \\
\hline
\end{tabular}


In Figure 4, a representative MS spectrum of GSH is shown, used to determine an ion and its intensity, from glutathione solution. Glutathione has $\mathrm{m} / \mathrm{z}$ mass to charge of 307 . However, this LC-MS method lacks specificity.

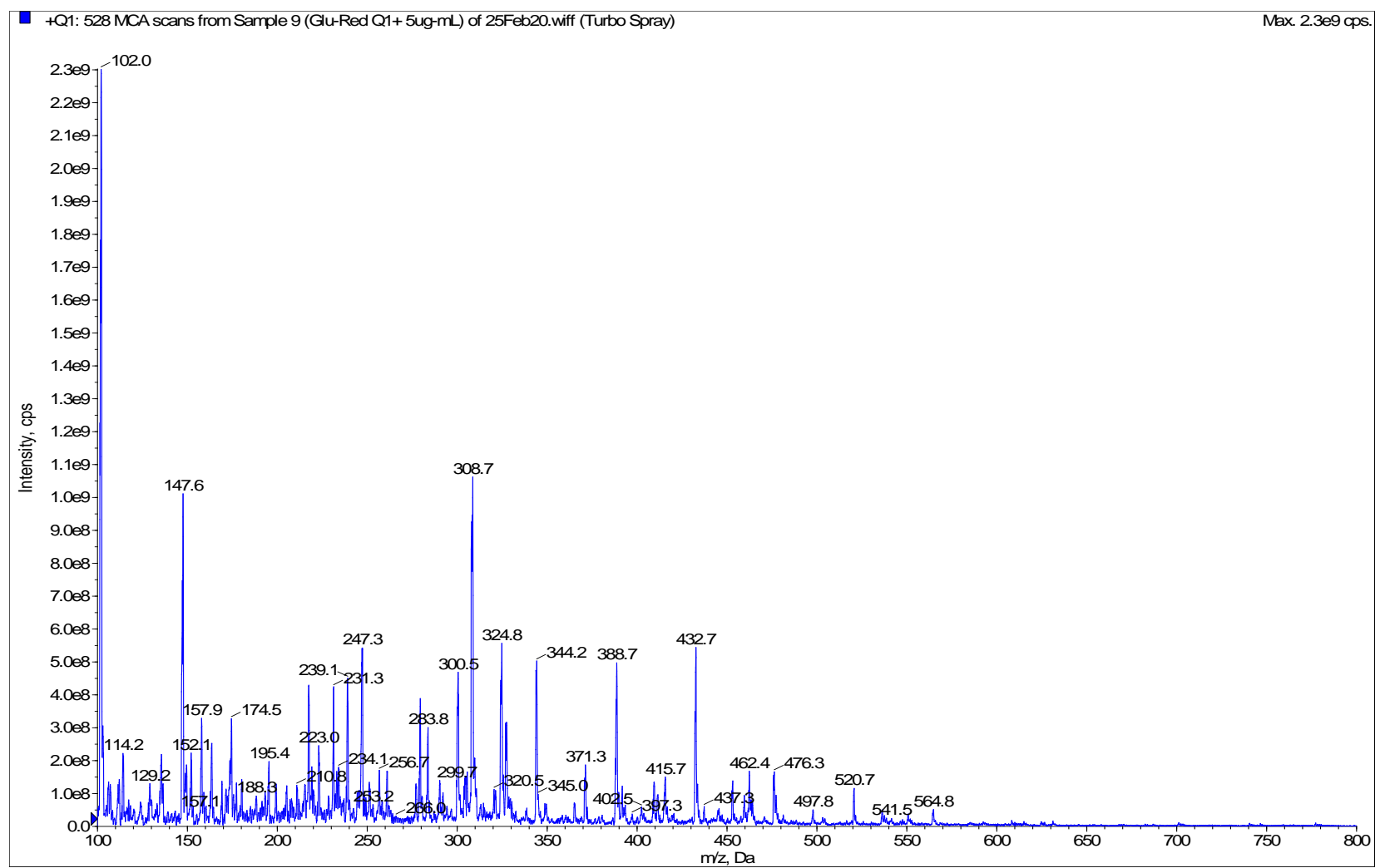

\section{Figure 4. MS spectra for GSH}

In Figure 5, a representative MS spectrum of GSSG is shown, used to determine an ion and its intensity, from glutathione solution. Glutathione has $\mathrm{m} / \mathrm{z}$ mass to charge of 612 . 
bioRxiv preprint doi: https://doi.org/10.1101/2020.04.26.058412; this version posted April 28, 2020. The copyright holder for this preprint (which

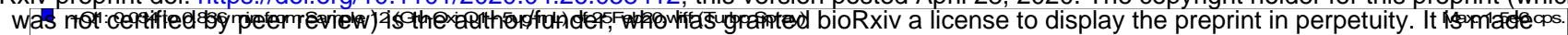

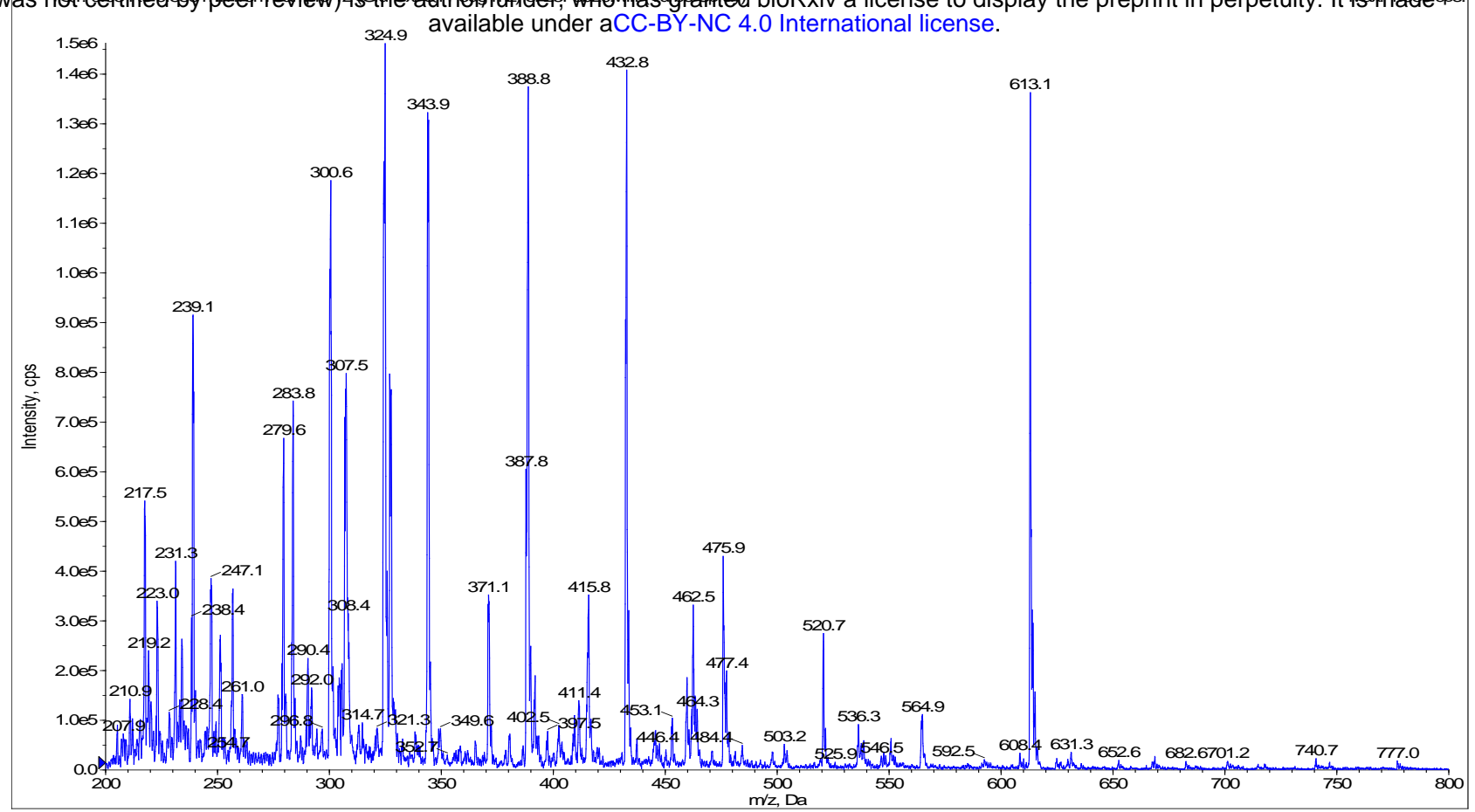

Figure 5. MS spectra for GSSG

MS/MS methods. A summary of the MS/MS method for GSH and GSSG is shown in table 2. The transition monitored for GSH m/z 307 to 179 . The transition monitored for GSSG m/z 612 to 483 . The collision energy $20 \mathrm{eV}$ for both GSH and GSSG.

Table 2. Summary of MS/MS parameters for GSH and GSSG

\begin{tabular}{cccccc}
\hline $\begin{array}{c}\text { Compound } \\
\text { ID }\end{array}$ & $\begin{array}{c}\text { Compound } \\
\text { Name }\end{array}$ & $\begin{array}{c}\text { Transition } \\
\text { Monitored }\end{array}$ & $\begin{array}{c}\text { Dwell } \\
\text { Time } \\
(\mathrm{msec})\end{array}$ & $\begin{array}{c}\text { Collision } \\
\text { Energy } \\
(\mathrm{eV})\end{array}$ & $\begin{array}{c}\text { Approximate } \\
\text { Retention } \\
\text { Time (min) }\end{array}$ \\
\hline Analyte 1 & GSH & $\mathbf{3 0 7 \rightarrow 1 7 9}$ & $\mathbf{1 0 0}$ & $\mathbf{2 0}$ & $\mathbf{0 . 2}$ \\
Analyte 2 & GSSG & $\mathbf{6 1 2} \rightarrow \mathbf{4 8 3}$ & 100 & 20 & 0.2 \\
\hline
\end{tabular}

In Table 2, the MS/MS method that we have developed for determining GSH and GSSG is shown. We determined from the MS spectrums that GSH and GSSG had 307 and 612 ions respectively, and we used the LCMS/MS method to break these ions, and test for the amount of product ions, giving us 179 product ions of GSH, and 483 for GSSG (Figures 6, 7). 
bioRxiv preprint doi: https://doi.org/10.1101/2020.04.26.058412; this version posted April 28, 2020. The copyright holder for this preprint (which

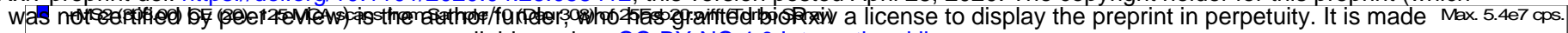

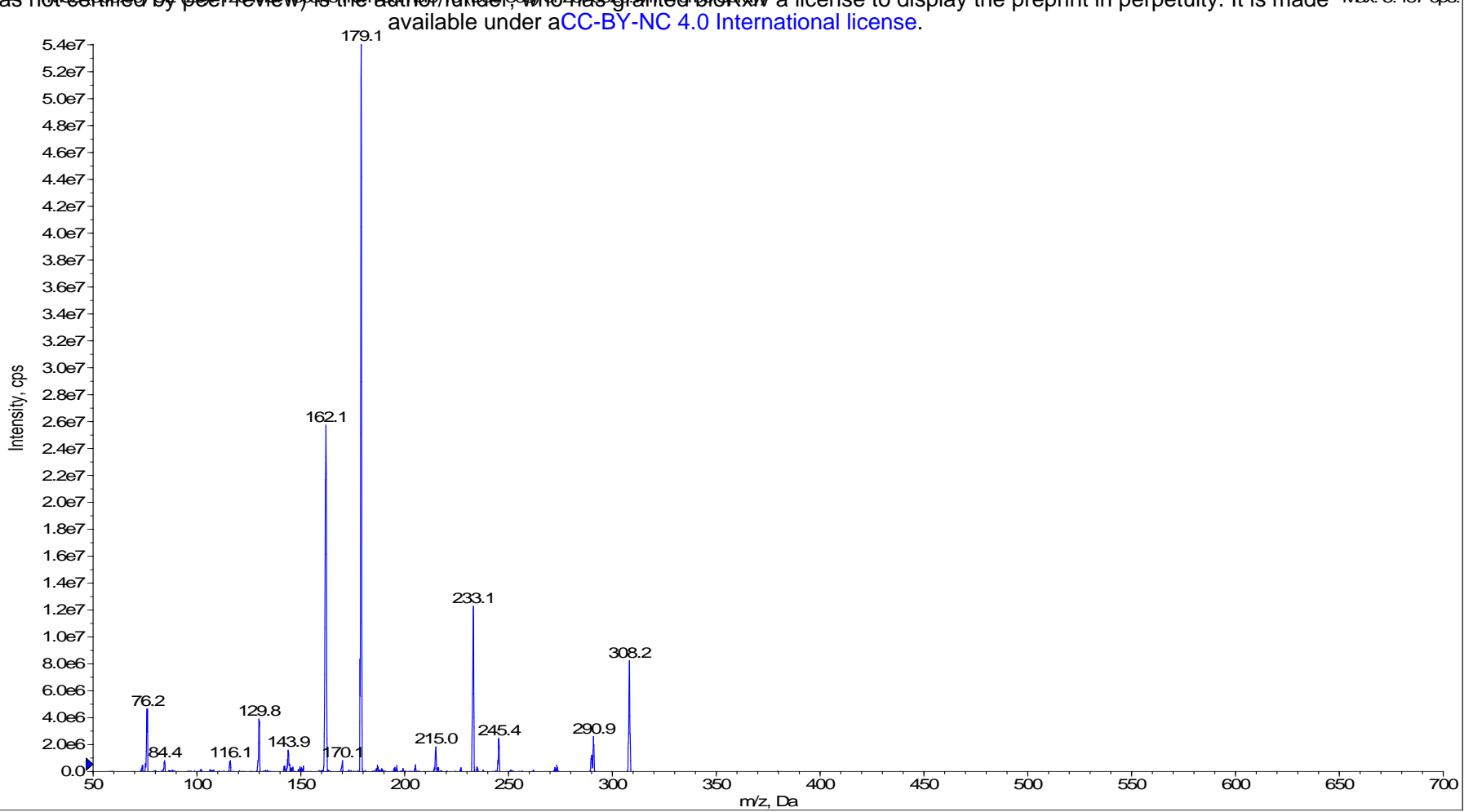

Figure 6. MS/MS spectra for GSH

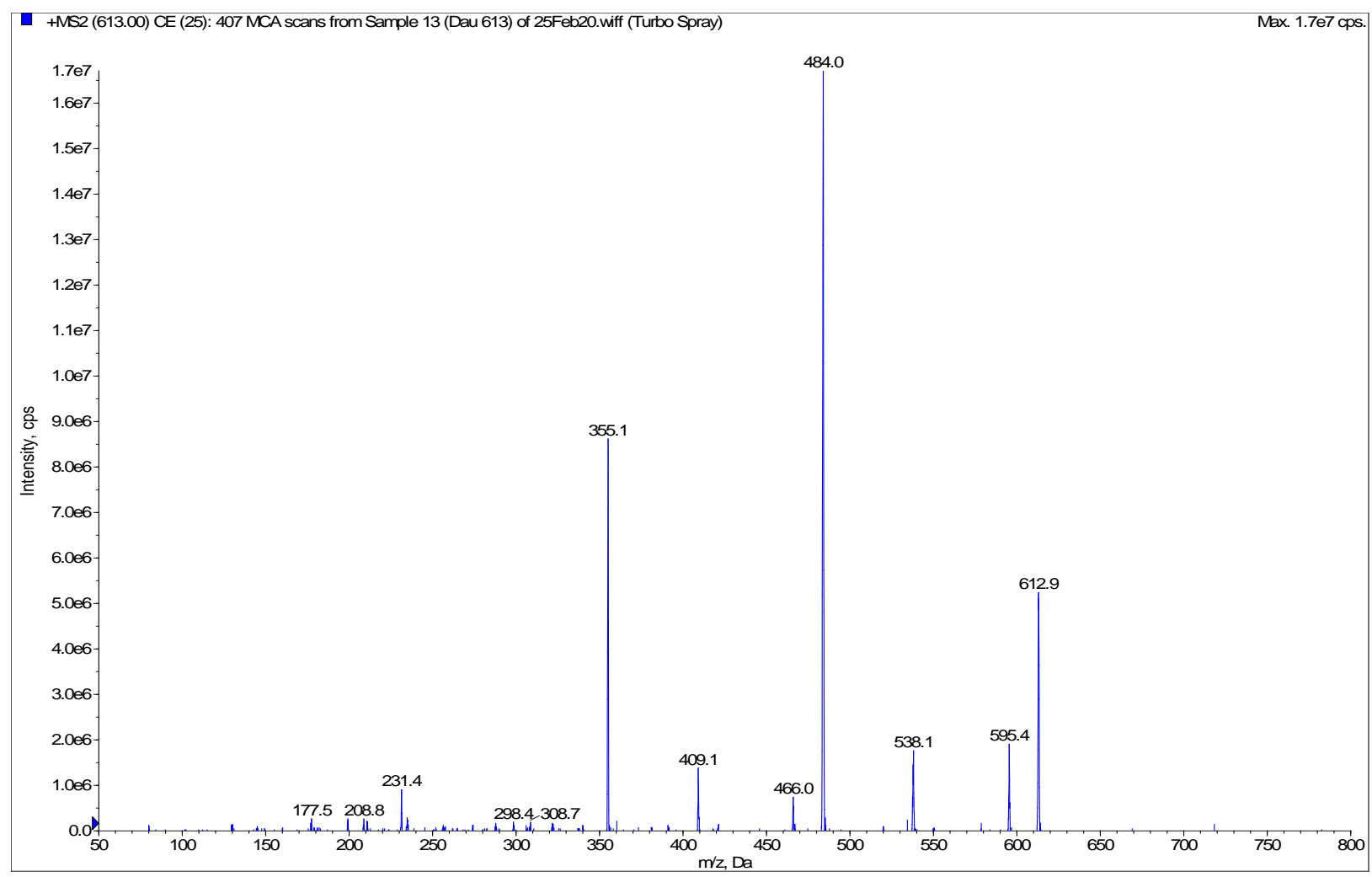

Figure 7. MS/MS spectra for GSSG

We made chromatograms using ion intensity (Figures 8, 9). 
bioRxiv preprint doi: https://doi.org/10.1101/2020.04.26.058412; this version posted April 28, 2020. The copyright holder for this preprint (which

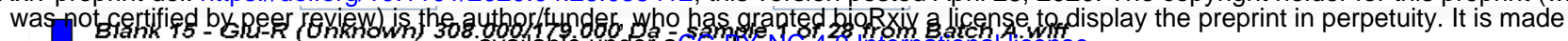

Area: $1.69 \mathrm{e}+002$ counts Height ayalabieb'

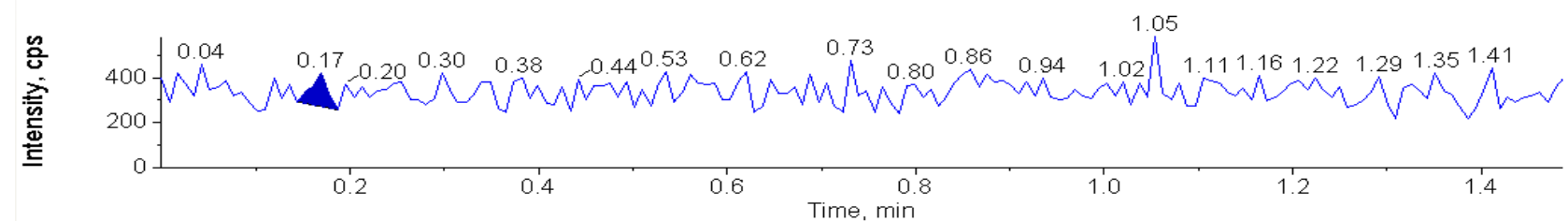

Glu-R2 (10ng) - Glu-R (Standard) 308.000/179.000 Da - sample 6 of 28 from Batch A.wiff

Area: $7.28 \mathrm{e}+005$ counts Height: $1.49 \mathrm{e}+005 \mathrm{cps}$ RT: $0.105 \mathrm{~min}$

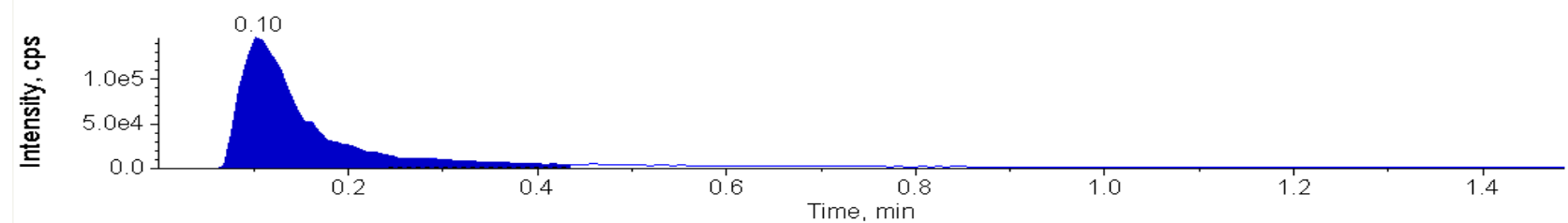

Glu-R5 - Glu-R (Standard) 308.000/179.000 Da - sample 17 of 28 from Batch A.wiff

Area: $4.90 e^{+006}$ counts Height: $1.03 e^{+006}$ cps RT: 0.106 min

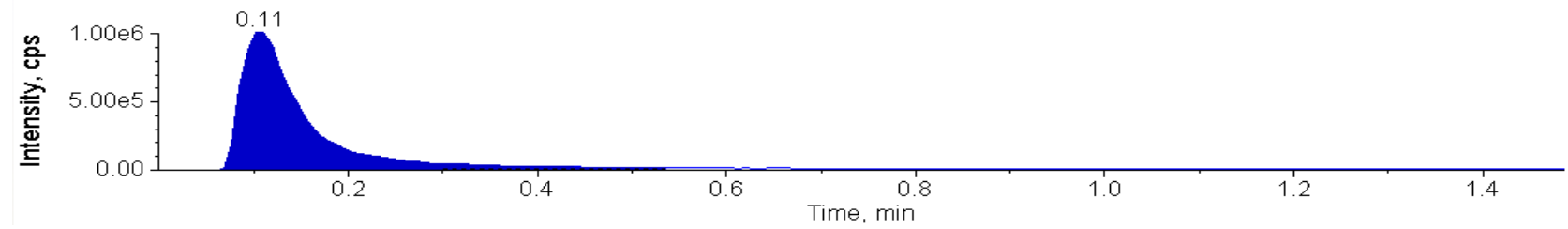

Figure 8. Representative chromatograms of (A) blank, (B) 10ng GSH and (C) 1000 ng GSH calibration standard

Blank - Glu-O (Blank) 613.000/484.000 Da - sample 1 of 23 from Batch B.wiff

Area: $3.06 \mathrm{e}+000$ counts Height: $8.17 \mathrm{e}+000 \mathrm{cps}$ RT: $0.131 \mathrm{~min}$

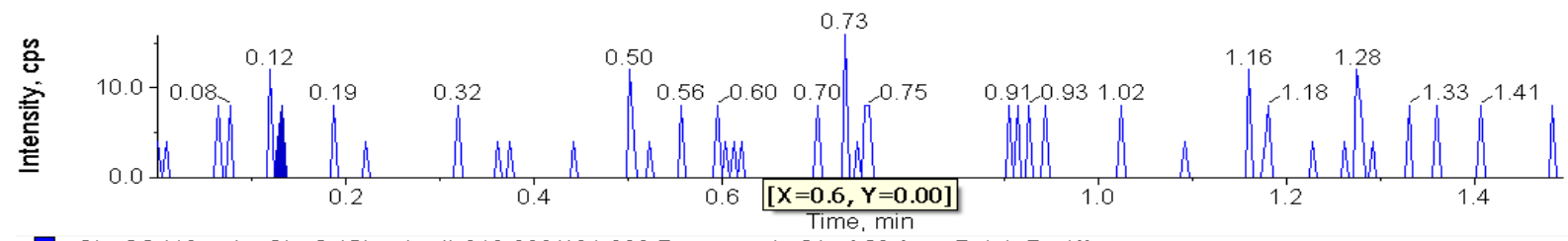

Glu-O2 (10 ng) - Glu-O (Standard) 613.000/484.000 Da - sample 21 of 23 from Batch B.wiff

Area: $1.64 e^{+003}$ counts Height: $5.43 e+002$ cps RT: 0.102 min

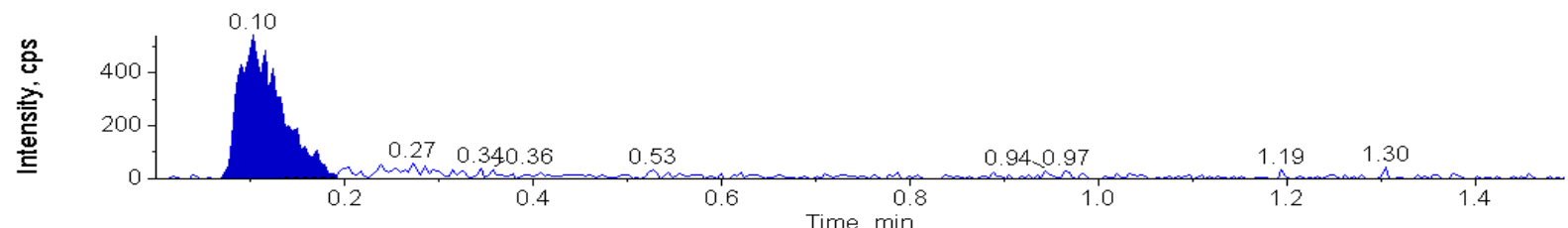

Glu-O5 (1000 ng) - Glu-O (Standard) 613.000/484.000 Da - sample 6 of 23 from Batch B.wiff

Area: $4.82 \mathrm{e}+004$ counts Height: $1.37 \mathrm{e}+004 \mathrm{cps}$ RT: $0.101 \mathrm{~min}$

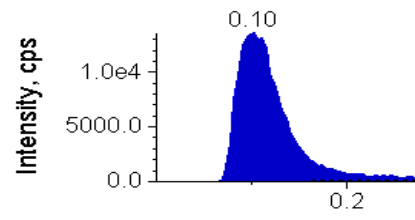

0.4

0.6

Time min

Figure 9. Representative chromatograms of (A) blank, (B) 10ng GSSG and (C) $1000 \mathrm{ng}$ GSSG calibration standard 

representative calibration cure for GSSG.

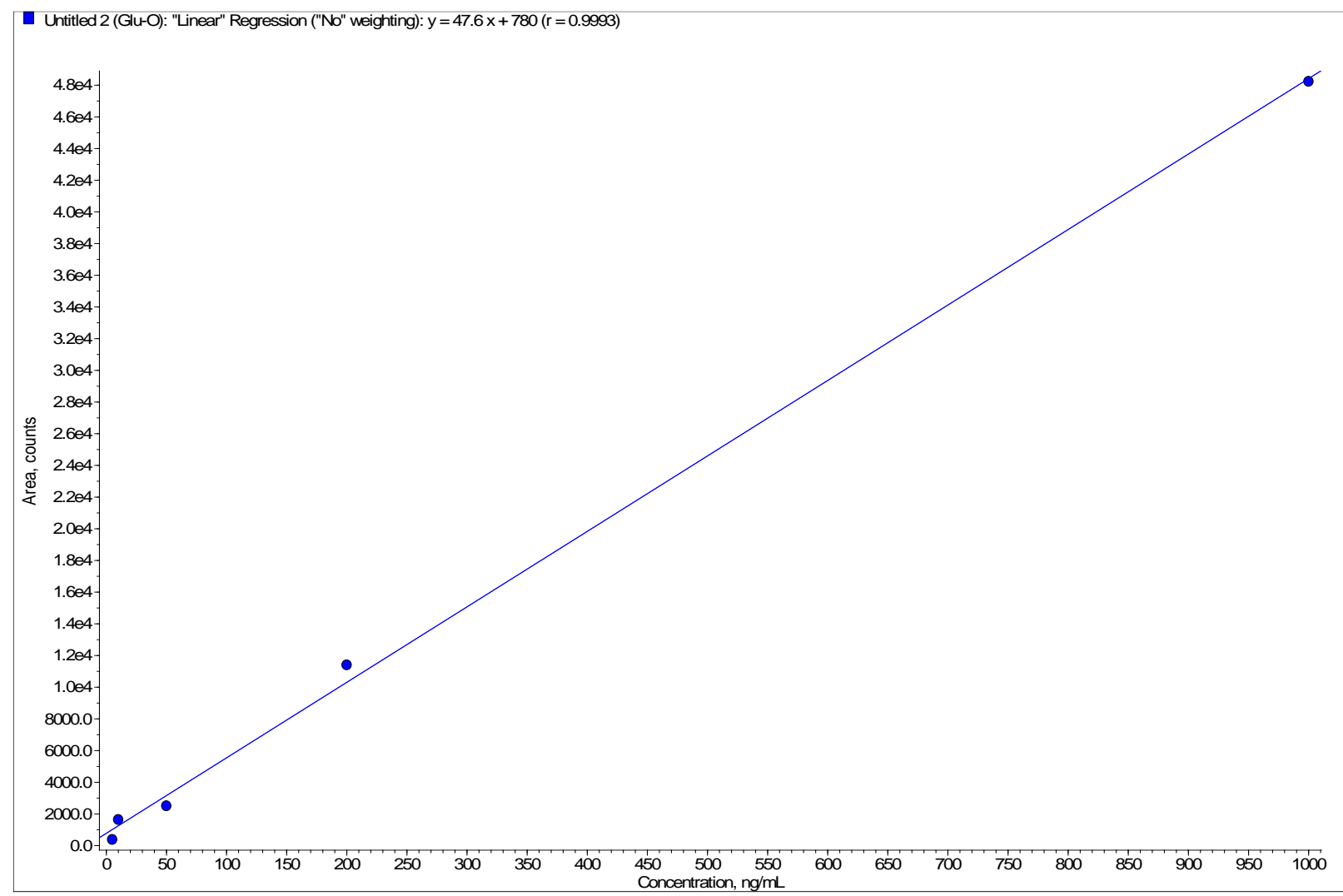

Figure 10. Representative of the standard calibration curve for GSSG

\section{Conclusion}

Although there are several methods available to test for the GSH to GSSG ratio, all have disadvantages including the need to generate derivatives, the inability to conveniently measure both GSH and GSSG, and lack of enough sensitivity to allow detection in very small samples. This method solves all these problems and creates an extremely fast and reliable method. However, in our original method, and first test, the glutathione standard was not stable. We overcame this challenge by adding formic acid to the solution and storing it at $4^{\circ} \mathrm{C}$ as soon as we were done preparing the sample, giving us stability for at least 2 weeks. A quantitative procedure for the determination of GSH and GSSG, over the concentration range of 5.00-1,000 ng/mL, has been successfully developed and proved to be sensitive, specific, linear, precise and accurate. The method utilized a sample volume of $0.0100 \mathrm{~mL}$. We developed a HPLC-MS/MS method that is fast, selective, highly sensitive, and multiple compound detectable that has the potential to be used as potential biomarker for cancer. 


\section{Future work.}

We will perform flow cytometry for single cell analysis to develop a simple approach to correlate the immune cell and glutathione. The correlation of immune cells and glutathione level in blood can be used as a screening tool. There have been no studies exploring it, therefore, we purpose to develop an assay to address this correlation with potential to be used as biomarker model for cancer screening.

\section{References}

1. Ortega Al, et. al., Glutathione in cancer cell death. Cancers (Basel). 2011 Mar 11;3 (1):1285-310.

2. Nicola Traverso, et. Al., Role of Glutathione in Cancer Progression and Chemoresistance. Oxidative Medicine and Cellular Longevity, Volume 2013, Article ID 972913, 1-10

3. Ankita Bansal, et. Al., Glutathione metabolism in cancer progression and treatment resistance. J. Cell Biol. 2018 Vol. 217 No. 7 2291-2298

4. Radu Albulescu, et. al., Mass Spectrometry for Cancer Biomarkers. Open access peer-reviewed chapter. IntechOpen.

5. Hui Wang, et. al., The clinical impact of recent advances in LC-MS for cancer biomarker discovery and verification. Expert Rev Proteomics. 2016; 13(1): 99-114.

6. David B. Liesenfeld, et. al., Review of Mass Spectrometry-Based Metabolomics inCancer Research. Cancer Epidemiol Biomarkers. 4, 2013, 2182-2201

7. Susen Becker, et. al., LC-MS-based metabolomics in the clinical laboratory. Journal of Chromatography B. Volumes 883-884, 1 February 2012, Pages 68-75. 